\title{
Atjaunojamo energoresursu tiesiskuma nodrošinājums
}

\author{
Kristīne Šelepova \\ Rìgas Stradina universitāte, \\ Juridiskā fakultāte, Latvija
}

\section{Kopsavilkums}

Energoresursu pieejamība ir garantija valsts ekonomiskajai attīstībai un labklājībai. Latvijas elektroenergíjas tirgus pēdējā desmitgadē piedzìvo būtiskas pārmaiñas. Eiropas Savienības regulu un direktīvu harmonizācija nacionālajos normatīvajos aktos ir veicinājusi Latvijas elektroenerğijas tirgus liberalizāciju, kā arī atjaunojamo energoresursu izmantošanas paplašināšanu Latvijā. Raksta mērḳis ir apzināt atjaunojamo energoresursu tiesisko regulējumu, tā atbalsta shēmas un problemātiku. Raksta autore skaidro, vai šo tiesību aizsardzības līmenis ir pietiekams, vai ir pieṇemtas nepieciešamās materiālo tiesību normas, kā arī vai ir pietiekoši tiesiskie lïdzekḷi, kas nodrošina šo tiesību aizsardzības ievērošanu, kā arī nākamos soḷus energoresursu liberalizācijas posmos. [1] ražošana.

Atslēgvārdi: atjaunojamie energoresursi; energoresursu tirgus; elektroenergíijas

\section{levads}

Atbalsts atjaunojamo energoresursu izmantošanai pastāv visās Eiropas Savienības valstīs. Starp Baltijas valstīm atbalsts atjaunojamiem energoresursiem un efektīvai kogenerācijai, un bāzes jaudām vislielākais ir Lietuvā un Latvijā, bet vismazākais Igaunijā. AS "Latvenergo" kā publiskajam tirgotājam ir normatīvajos aktos uzlikts pienākums iepirkt elektroenerğiju no ražotājiem, kas elektroenerǵiju ražo, izmantojot atjaunojamos energoresursus, un kogenerācijā. Normatīvie akti nosaka arī kārtību, kādā publiskajam tirgotājam šã iepirkuma papildu izmaksas tiek kompensētas - visi elektroenerǵijas galalietotāji proporcionāli to elektroenerǵijas patērin̦am maksā obligātā iepirkuma komponenti, kuras aprēḳina metodiku nosaka regulators. Elektroenerğijas tirgus likumā ir nostiprināts mērḳis atjaunojamo energoresursu īpatsvara palielinājumam Latvijas elektroenergíjas patēriṇā. 
Pamatojoties uz nozares specifiku un to, ka darba tēmai nav plašas publikācijas, autore darba rakstǐšanā izmantoja gan Eiropas Savienības direktīvas, gan Latvijas Republikas likumus un Ministru kabineta noteikumus, kā arī praktisko darba pieredzi, kas gūta darba tiesiskajās attiecībās energétikas nozarē jau kopš 2007. gada.

\section{Atbalsta tiesiskais mehānisms elektroenerǵijas ražošanai no atjaunojamiem energoresursiem}

"Par atjaunojamajiem energoresursiem (AER) uzskata vēju, ūdeni, saules starojumu, biomasu (koksni, salmus, biogãzi, biodegvielu), zemes siltumu, viḷnus, kā arī paisuma bēguma procesus. Latvijā atjaunojamie energoresursi aizṇem vienu trešo daḷu primāro energoresursu bilancē, un divi visvairāk izmantotie atjaunojamo energoresursu veidi ir koksne un hidroresursi. Vēja enerǵija un biogāze tiek izmantota ievērojami mazākā apmērā. Saules enerǵiju šobrīd izmanto tikai l̦oti nelielos apjomos pilotprojektu formā. Atjaunojamie energoresursi var tikt izmantoti tieši vai arī pastarpināti, piemēram, no biomasas iegūstot transporta degvielas un cita veida šḳidro kurināmo". [2]

Atjaunojamajiem energoresursiem ir svarīga loma Eiropas Savienības politikā. Tã ir saistìta ar šo resursu izmantošanas pozitìvo ietekmi vairākos aspektos: iespējams ietaupīt fosilos energoresursus; samazināt izmešu daudzumu atmosfērā, augsnē un ūdenī; atjaunojamie energoresursi l̦auj dažādot energijijas ieguves veidus un avotus, izmantot vietējos resursus, tādējādi paaugstinot energoapgādes drošību un samazinot atkarību no enerǵijas importa; atjaunojamo energoresursu izmantošana l̦auj samazināt politiskos, vides un ekonomiskos riskus, kas pastāv uz fosiliem energoresursiem balstītā energoapgādes sistēmā; tā kā atjaunojamie energoresursi lielākoties ir vietējie resursi, tiek veicināta reǵionālā attīstība - radītas jaunas darbavietas, attīstās lauksaimniecība, mežsaimniecība, apstrādes rūpniecība un ar atjaunojamo energoresursu tehnologijām saistìtā pētniecība.

Latvijā par speciālajiem atjaunojamās enerǵijas jomu regulējošiem normatīvajiem aktiem ir uzskatāms 1998. gada 3. decembra Energèetikas likums, 2005. gada 5. maija Elektroenerǵijas tirgus likums un saskaņa ar to izdotie Ministru kabineta 2010. gada 16. marta noteikumi Nr. 262 "Noteikumi par elektroenerǵijas ražošanu, izmantojot atjaunojamos energoresursus, un cenu noteikšanas kārtību” un Ministru kabineta 2009. gada 10. marta noteikumi Nr. 221 "Noteikumi par elektroenergijas ražošanu un cenu noteikšanu, ražojot elektroenerğiju kogenerācijā", kā arī 2000. gada 19. oktobra likums "Par sabiedrisko pakalpojumu regulatoriem" un saskaṇā ar to izdotie Ministru kabineta noteikumi.

Saskan̄ā ar Eiropas Parlamenta un Padomes 2009. gada 23. aprīla Direktīvu 2009/28/EK "Par atjaunojamo energoresursu izmantošanas veicināšanu", ar ko groza un sekojoši atcel̦ Direktīvas 2001/77/EK un 2003/30/EK, Latvijai noteiktais vispārējais mērḳis ir palielināt no AER saražotās enerǵijas īpatsvaru kopējā enerǵijas bruto galapatēriñā līdz 40\% 2020. gadā. Direktīvas 25. pants nosaka: "Dalībvalstīm ir atškirīgs atjaunojamo energoresursu potenciāls, un tās izmanto dažādas atbalsta shēmas 
atjaunojamo energoresursu atbalstam valsts mērogā. Lielākā daḷa dalībvalstu piemēro atbalsta shēmas, ar kurām nodrošina priekšrocības vienīgi tai enerǵijai no atjaunojamajiem energoresursiem, ko ražo to teritorijā. Lai valsts atbalsta shēmas pareizi darbotos, ir būtiski, lai dalïbvalstis varētu kontrolèt savu valsts atbalsta shēmu ietekmi un izmaksas atbilstīgi savam atšḳirīgajam potenciālam. Svarīgs līdzeklis, kā panākt šajā direktīvā noteikto mērḳi, ir nodrošināt valsts atbalsta shēmu pareizu darbību atbilstīgi Direktīvai 2001/77/EK, lai tādējādi saglabātu ieguldītāju uzticību un dotu iespēju dalībvalstīm izstrādāt efektīvus valsts pasākumus mērḳu sasniegšanai”. [3]

Būtiskākie Direktīvas 2009/28/EK punkti nosaka: izveidot vienotu sistēmu no atjaunojamajiem energoresursiem saražotas enerǵijas izmantošanas veicināšanai; noteikt, ka no atjaunojamajiem energoresursiem saražotas enerǵijas īpatsvars 2020. gadā Latvijā ir vismaz 40\% no kopējā enerǵijas bruto galapatēriņa; noteikt, ka no atjaunojamajiem energoresursiem saražotas enerǵijas īpatsvars visā transportā 2020. gadā Latvijā ir vismaz 10\% no energiijas galapatēriņa transportā; izklāsta noteikumus par statistisko pārdali dalībvalstu starpā, par kopīgiem dalībvalstu un trešo valstu projektiem, izcelsmes apliecinājumiem, administratīvajām procedūrām, informāciju un mācībām, kā arī no atjaunojamajiem energoresursiem saražotās energíjas pievadi elektrotīkliem; tie arī nosaka ilgtspējīgus kritērijus biodegvielai un biologiskajiem šķidrajiem kurināmajiem.

Direktīva 2009/28/EK ir Eiropas Savienības enerǵêtikas politikas vēsturē pirmais mēginājums radìt visaptverošu tiesisko ietvaru atjaunojamo energoresursu izmantošanas veicināšanai galvenajos energêetikas sektoros: elektrības ražošanā, siltumapgādē, dzesēšanas un transporta sektoros. Lai veicinātu Direktīvas 2009/28/EK prasību izpildi 2010. gada 16. martā tika pieñemti Ministru kabineta noteikumi Nr. 262 "Noteikumi par elektroenergijas ražošanu, izmantojot atjaunojamos energoresursus, un cenu noteikšanas kārtïbu".

Latvija par atbalsta instrumentu ir izvēlējusies elektroenergíijas obligātā iepirkuma mehānismu, kas ir viens no garantēta iepirkuma paveidiem. Valsts pārvaldi atjaunojamo energoresursu jomā pārstāv Ekonomikas ministrija, kas ar Energétikas departamenta starpniecību īsteno energeetikas pārvaldes funkcijas, izstrādājot energétikas politikas, dokumentus un tiesỉbu aktu projektus, tostarp arī atjaunojamo energoresursu jomā, veicinot enerğijas lietotājiem piegādāto energoresursu efektīvu un ekonomisku izmantošanu, sekmējot investīciju piesaistīšanu energétikā, kā arī energoapgādes komersantu objektu modernizācijā un būvniecībā. Jaunu elektroenerǵijas jaudu ieviešanai, plānojot ražot elektroenergiiju no atjaunojamo energoresursiem, vispirms ir nepieciešama Ekonomikas ministrijas izdota aț̣auja elektroenergijas ražošanas jaudu palielināšanai vai jaunu jaudu ieviešanai. Gadījumos, ja plānotā elektriskā jauda pārsniedz 1 MW, komersantiem nepieciešams saṇemt arī Sabiedrisko pakalpojumu regulēšanas komisijas licenci elektroenergijas ražošanai.

Analizējot atjaunojamo energoresursu veidus pēc to potenciāla un iespējamā devuma nākotnē, lai izvērtētu primāri atbalstāmos atjaunojamo energoresursu veidus mērḳa izpildīšanā Latvijā, par galvenajiem izmantojamiem resursiem tiek novērtēta biomasa, galvenokārt koksne, kā arī vēja energíija, biogāze un hidroenergija. Šo resursu 
potenciāls nav vēl pilnībā izmantots. Tāpēc galvenais stratēgiskais mērḳis atjaunojamo energoresursu jomā ir optimāla Latvijas atjaunojamo energoresursu potenciāla izmantošana, ṇemot vērā ekonomiskās, geoogrāfiskās un tehniskās iespējas, kā arī pēc ekonomiskajiem, vides un enerğètikas attīstības aspektiem, vienlaikus ṇemot vērā starptautiskos un Eiropas Savienības politikas mērḳus un prasības attiecībā uz atjaunojamajiem energoresursiem. Eiropas Savienības normatīvo dokumentu harmonizācija nacionālajos tiesību aktos sniedz obligāti pildāmas prasības un sasniedzamos kvantitatīvos mērķus atjaunojamo energoresursu īpatsvara palielināšanā, siltumnīcefekta gāzu izmešu samazināšanā un energoefektivitātes paaugstināšanā.

Lai gan atjaunojamo energoresursu nozīme valsts ekonomikā ir l̦oti svarīga, sabiedrības attieksme nav vienāda, un bieži vien tā ir pat negatīva. Piemēram, SIA "Energy Investment" Cēsīs plānoja būvēt biogāzes kogenenerācijas kompleksu ar kopējo jaudu 2,4 megavati. Enerğiju bija paredzēts ražot no atjaunojamiem resursiem - kukurūzas, zāles, sausajiem kūtsmēsliem. Stacija ražotu gan siltumenerǵiju, gan elektroenerǵiju. Veicot šìs ieceres sabiedrisko aptauju, viedokli par kogenerācijas stacijas būvniecību izteica vairāk nekā 2000 cilvēku, un gandrīz visi bija pret šā objekta būvniecību Cēsu pilsētā, norādot, ka vēlas dzìvot tīrā vidē un elpot tīru gaisu, kā arī uzsverot Cēsu kā kultūras un tūrisma pilsētas nozīmi. Pamatojoties uz aptauju, Cēsu novada dome noraidīja SIA "Energy Investment" koǵenerācijas elektrostacijas būvniecības ieceri, par ko uzṇēmums vērsās ar pieteikumu Administratīvajā tiesā. Ar Administratīvās tiesas lēmumu tika ierosināta administratīvā lieta pēc SIA "Energy Investment" pieteikuma par pienākuma uzlikšanu Cēsu novada domei akceptēt biomasas kogenenerācijas būvniecības ieceres plānu un izsniegt plānošanas arhitektūras uzdevumu. SIA "Energy Investment" savā pieteikumā norādỉja, ka publiskās apspriešanas rezultātā iegūtais sabiedrības viedoklis nevar kalpot par pamatojumu būvniecības aizliegšanai un domes lēmumā nav norādīta neviena tiesību norma, uz kuras pamata dome būtu tiesīga aizliegt būvniecību. Patlaban gan Administratīvā tiesa nav pieņēmusi spriedumu šajā lietā, bet tas varētu kḷūt par tiesu prakses labu piemēru, ka sabiedrïbas viedoklis var ietekmēt atjaunojamo energoresursu ražošanas veidus.

\section{Obligātā iepirkuma atbalsta shēma, tā tiesiskās īpatnības}

Elektroenerğijas obligātais iepirkums ir valsts noteikts atbalsta mehānisms elektroenergíijas ražotājiem, paredzot tā finansēšanu no elektroenerǵijas galalietotāju maksājumiem. 2005. gada 5. maija Elektroenerğijas tirgus likuma 28. pantā un 29. pantā noteikts, ka ražotāji, kuri elektroenerğiju ražo efektīvā kog̀enerācijā vai elektroenergijas ražošanai izmanto atjaunojamos energoresursus, var iegūt tiesības pārdot saražoto elektroenergiiju obligātā iepirkuma ietvaros. 28. panta 2. dạ̣ā noteikts, ka: "Kritērijus, pēc kādiem koǵenerācijas elektrostacijas tiek kvalificētas šā panta pirmajā daḷā noteikto tiesību iegūšanai, obligātā iepirkuma un tā uzraudzības kārtību, elektroenerǵijas cenas 
noteikšanas kārtỉbu atkarībā no kogeneneāijas stacijas elektriskās jaudas un izmantojamā kurināmā, obligātā iepirkuma izmaksu segšanas kārtību un kārtību, kādā var atteikties no tiesībām pārdot saražoto elektroenergiju obligātā iepirkuma ietvaros, nosaka Ministru kabinets". [5] Tādi paši kritēriji tiek noteikti 29. panta 4. dạ̦ā attiecībā uz elektroenergiju, kas ražota, izmantojot atjaunojamos energoresursus: "Nosacījumus elektroenerǵijas ražošanai, izmantojot atjaunojamos energoresursus, kā arī kritērijus ražotāju kvalifikācijai šā panta pirmajā dạ̦ā noteikto tiesību saṇemšanai un kārtību, kādā var atteikties no tām, elektroenergijas cenas noteikšanas kārtību atkarībā no atjaunojamo energoresursu veida, obligātā iepirkuma apjoma noteikšanas, ìstenošanas un uzraudzības kārtību, obligātā iepirkuma apjoma izmaksu segšanas kārtību, kā arī pasākumus, lai veicinātu elektroenerǵijas ražošanu no biomasas, nosaka Ministru kabinets." [5]

Atbilstīgi 2005. gada 5. maija Elektroenerǵijas tirgus likuma 33. pantam AS "Latvenergo", kas pilda publiskā tirgotāja funkcijas, ir jāiepērk elektroenerǵija no koǵenerācijas stacijām un stacijām, kas izmanto atjaunojamos energoresursus, obligātā iepirkuma ietvaros. Ja minētiem elektroenerǵijas ražotājiem ir piešķirtas tiesības pārdot elektroenerğiju obligātā iepirkuma ietvaros, AS "Latvenergo" veic obligāto iepirkumu uz līguma pamata atbilstīgi minēto normatīvo aktu prasībām. Tiesības pārdot saražoto elektroenerǵiju obligātā iepirkuma ietvaros piešķir Ekonomikas ministrija. Nosacijjumus elektroenerǵijas ražošanai un cenu noteikšanas kārtību regulē Ministru kabineta noteikumi, t. i., 2010. gada 6. marta Ministru kabineta noteikumi Nr. 198 "Noteikumi par elektroenergiijas ražošanu, izmantojot atjaunojamos energoresursus, un cenu noteikšanas kārtību"; 2011. gada 29. novembra Ministru kabineta noteikumi Nr. 914 "Elektroenerğijas tirdzniecỉbas un lietošanas noteikumi".

AS "Latvenergo" katru gadu aprēkina un publicē precizētu no atjaunojamiem energoresursiem saražotās elektroenergijas apjomu turpmākajiem gadiem, n̦emot vērā iepriekšējā gada faktiskos rādìtājus.

Elektroenerǵijas obligātā iepirkumu cena ir daudzkārt augstāka nekā pieejamā elektroenergíijas cena tirgū. Rezultātā rodas papildu izmaksas, kas būtībā veidojas no obligātā iepirkuma un tirgus sektora cenu starpỉbas. Šìs papildu izmaksas veido obligātā iepirkuma komponentes, kuras apstiprina Sabiedrisko pakalpojumu regulēšanas komisija. Saistītajam lietotājam šīs izmaksas tiek apkopotas un piemērotas elektroenerǵijas tarifā, savukārt tirgus dalībniekiem - proporcionāli to elektroenergiijas patēriṇa apjomam - jāmaksā par katru komponenti.

Atbilstīgi 2009. gada 19. augusta Sabiedrisko pakalpojumu regulēšanas komisijas padomes lēmumā Nr. 1/2 apstiprinātajai obligātā iepirkuma komponenšu aprēkinināšanas metodikai, obligātā iepirkuma komponentes regulators apstiprina un publicē vienu reizi gadā, un tās attiecīgi stājas spēkā katru gadu 1. aprīlì. Obligātā iepirkuma komponentes izmaiṇas ir saistītas ar publiskā tirgotāja AS "Latvenergo" izmaksu izmaiṇām elektroenerǵijas iepirkšanai no atbalstāmajiem elektroenerǵijas ražotājiem. Normatīvie akti paredz - lai veicinātu elektroenerǵijas ražošanas attīstību Latvijā, 
noteiktiem ražotājiem (kas ražo elektroenerğiju efektīvā kogenenēcijā vai no atjaunojamiem energoresursiem - tās ir biomasas un biogāzes ražotnes, mazās hidroelektrostacijas un vēja stacijas) ir tiesības pārdot elektroenerǵiju par atbalsta cenu, kas ir augstāka nekā elektroenerǵijas tirgus cena. Elektroenerğiju no minētajiem ražotājiem par atbalsta cenu iepērk AS "Latvenergo" - šis pienākums ir noteikts Sabiedrisko pakalpojumu regulěšanas komisijas izsniegtajā elektroenerğijas tirdzniecības licencē. Lai kompensētu AS "Latvenergo" izdevumus, kas uzṇēmumam radušies, iepērkot obligāti iepērkamo elektroenerğiju, regulators apstiprina obligātā iepirkuma komponentes, kuras maksā visi Latvijas elektroenergijas galalietotāji proporcionāli to elektroenergijias patērina apjomam. Atbilstīgi 2011. gada 29. novembra Ministru kabineta noteikumu Nr. 914 41. pantam: "Lietotājs - elektroenerğijas tirgus dalībnieks - proporcionāli elektroenerğijas patēriṇam maksā par katru obligātā iepirkuma komponenti. Par obligātā iepirkuma komponenti maksā attiecīgajam elektroenerǵijas pārvades vai sadales sistēmas operatoram kopā ar maksu par pārvades vai sadales sistēmas pakalpojumiem." [7] Savukārt saistītajam lietotājam šīs izmaksas tiek apkopotas un piemērotas elektroenergijas tarifā.

Apstiprinātās komponentes kompensē publiskajam tirgotājam obligātā iepirkuma radìtos papildu izdevumus, salīdzinot ar tāda paša apjoma elektroenerğijas iepirkumu elektroenerğijas tirgū. Kā jau minēts iepriekš, atbalsta elektroenerğijas cena ražotājiem tiek noteikta, lai radītu viņiem ekonomiski pamatotu interesi darboties Latvijas teritorijā un nodrošinātu, lai valsts teritorijā tiktu saražota pēc iespējas lielāka daḷa no elektroenergíijas patērētājiem nepieciešamā elektroenerǵijas apjoma.

Arī citās Eiropas Savienības valstīs elektroenerğijas izmaksās lietotājiem tiek iekḷautas obligātā iepirkuma komponentes, bet katrā valstī obligātā iepirkuma atbalsts un tā iekḷaušana elektroenerǵijas tarifā tiek veidota atšḳirīgi un arī n̦emot vērā katras valsts specifiku elektroenerǵijas ražošanā, piemēram, Igaunijā šì komponente ir mazāka nekā Latvijā, jo Igaunijā elektroenergiija, kas saražota izmantojot atjaunojamos energoresursus un kogeneneācijā, ir krietni mazākā apjomā nekā Latvijā. Daḷā Eiropas Savienības valstu šīs komponentes tiek pieskaitìtas pie pārvades vai sadales tarifa.

2010. gada 16. martā tika izdoti Ministru kabineta noteikumi Nr. 262 "Noteikumi par elektroenerǵijas ražošanu, izmantojot atjaunojamos energoresursus, un cenu noteikšanas kārtību", kas ietver nosacījumus elektroenerǵijas ražošanai, izmantojot atjaunojamos energoresursus, kā arī kritērijus ražotāju kvalifikācijai tiesību iegūšanai pārdot no atjaunojamo energoresursu saražoto elektroenergiju obligātā iepirkuma ietvaros. Atbilstīgi noteikumiem obligātā iepirkuma tiesību pieškirš̌ana biomasas, biogāzes, saules un vēja elektrostacijām notika konkursa kārtībā. Komersants varēja iegūt arī tiesības saṇemt garantēto maksu par elektrostacijā uzstādìto elektrisko jaudu. Piešķirtais atbalsta termiṇš no ekspluatācijas uzsākšanas brīža ir noteikts 10 gadu periodam, un pèc šā laika turpmākos 10 gadus tiek piemērots samazināts atbalsta apmērs. No 2011. gada 26. maija ministrija konkursus par tiesību iegūšanu pārdot elektrostacijās saražoto elektroenerǵiju obligātā iepirkuma ietvaros neorganizē, 
un ražotājs nevar kvalificēties elektroenerğijas pārdošanai obligātā iepirkuma ietvaros un tiesību iegūšanai saṇemt garantētu maksu par uzstādīto elektrisko jaudu.

Ministru kabineta 2009. gada 10. marta noteikumi Nr. 221 "Noteikumi par elektroenerğijas ražošanu un cenu noteikšanu, ražojot elektroenerǵiju koǵenerācijā" savukārt regulē kogenerācijas procesā saražotas elektroenerğijas obligāto iepirkumu par noteiktu cenu, kā arī tiesības uz garantētas maksas par koǵenerācijas elektrostacijā uzstādīto elektrisko jaudu saṇemšanu. Esošās vai plānotās kogenerācijas stacijas, kas izmanto atjaunojamos energoresursus, atbalstam varēja pieteikties lìdz 2012. gada 9. septembrim. Vienlaikus, uzlabojot atbalsta mehānismu, ar Ministru kabineta 2012. gada 28. augusta noteikumiem Nr. 604 "Grozijumi Ministru kabineta 2009. gada 10. marta noteikumos Nr. 221 "Noteikumi par elektroenerǵijas ražošanu un cenu noteikšanu, ražojot elektroenerǵiju koǵenerācijā"” noteikts atbalsta terminna ierobežojums - 10 gadi (koǵenerācijas elektrostacijām, kuru uzstādītā elektriskā jauda nepārsniedz $4 \mathrm{MW}$ ) un 15 gadi (kogenerācijas elektrostacijām, kuru uzstādītā elektriskā jauda ir lielāka par $4 \mathrm{MW}$ ) garantētai maksai.

Pēdējā laikā lielu publicitāti ir saṇēmis obligātā iepirkuma komponentes pieaugums 2013. gada 1. aprīlī. Salīdzinājumam - 2012. gadā tika apstiprināta summārā obligātā iepirkuma komponente par kogenerācijā un no atjaunojamiem energoresursiem saražotās elektroenerǵijas iepirkumu - 12,30 Ls/MWh, bet 2013. gadā 18,90 Ls/MWh, kas vidēji veido 35\% pieaugumu.

Šāds pieaugums ir saistîts ar palielinātajām cenām: iepirkuma cenu no vēja stacijām, hidroelektrostacijām, biomasu un biogāzi izmantojošām elektrostacijām, tāpat obligātās iepirkuma komponentes palielinājums ir saistìts ar gāzes cenu svārstībām, kas tieši ietekmē iepērkamās elektroenerǵijas cenu. Kopumā tas rada ne tikai risku samazināt elektroenerǵijas lietotāju maksātspēju, kā arī uzṇēmumu konkurētspēju, radot draudus valsts tautsaimniecíbai. Tādēḷ 2012. gadā turpmāka tiesību pieškiriršana pārdot elektroenerǵiju obligātā iepirkuma ietvaros vai saṇemt garantētu maksu par elektrostacijā uzstādìto jaudu, lai sakārtotu un uzlabotu esošo atbalsta sistēmu kopumā, ir apturēta. Lìdz 2016. gada 1. janvārim jauni komersanti nevar kvalificēties tiesību iegūšanai pārdot saražoto elektroenerğiju obligātā iepirkuma ietvaros un tiesību iegūšanai saṇemt garantētu maksu par elektrostacijā uzstādīto elektrisko jaudu.

2013. gada 27. martā Sabiedrisko pakalpojumu regulēšanas komisija ir izstrādājusi un publicējusi priekšlikumus obligātā iepirkuma komponenšu reālai samazināšanai. "Regulatora priekšlikumi attiecas gan uz visu veidu elektroenerǵijas ražotājiem, gan uz iespējamām izmaiṇām nodokḷu politikā: pārskatìt atbalstāmajiem ražotājiem noteiktās cenu veidošanas formulas, un tās veidot no diviem saskaitāmajiem - cenas mainīgās daļas, kas atkarīga no mainīgajām izmaksām, un cenas pastāvīgās dạ̦as, kas atkarīga no elektrostacijas veida un jaudas; atcelt piesaisti dabas gāzes cenām, tā var tikt saglabāta tikai tām elektrostacijām, kas izmanto dabas gāzi; stimulēt ražošanas efektivitāti un atbalstu attiecināt tikai uz investīciju atgūšanas periodu - cenas pastāvīgās daḷas saskaitāmā koeficienti jāizvēlas tā, lai pie optimālas jaudas izmantošanas, investīcijas 
būtu atgūstamas noteiktā laikā ar saprātīgu atdeves likmi; paredzēt atbalsta intensitātes samazināšanu, ja elektrostacijas projekts ir sanēemis vai saṇems investīciju atbalstu citu atbalsta programmu ietvaros, piemēram, no ES fondiem; noteikt būtisku atbalsta intensitātes samazinājumu koǵenerācijas elektrostacijām, kuru uzstādītā elektriskā jauda ir lielāka par $4 \mathrm{MW}$, modificējot formulas gan energijas, gan jaudas komponentei tā, lai samazinātu saṇemto atbalsta apjomu, jaudas komponentes noteikšanā izmantojot ražošanas alternatīvas etalonu - efektīvas gāzes kombinētā cikla kondensācijas elektrostacijas pastāvīgajām izmaksām, komponentes lielumu nosakot atkarībā no uzstādītās jaudas - jo lielāka jauda, jo mazāka jaudas komponente, kā arī jaudas komponentes noteikšanas formulā iestrādājot mehānismu, kas stimulē elektrostacijas īpašnieku pārdot elektroenerǵiju tirgū, lai atgūtu ne tikai mainīgās, bet arī pastāvīgās izmaksas, un tādējādi nepieḷaujot, ka pie labvēlīgiem tirgus apstākḷiem pastāvīgās izmaksas tiktu atgūtas lielākā apmērā nekā nepieciešams; veikt izmaiņas nodokḷu politikā, akcīzes nodokli dabasgāzei nenosakot lielākā apmērā, kā to paredz ES, un tādējādi samazināt gan nodokḷa likmi, gan apliekamo bāzi." [9]

\section{Secinājumi}

Atjaunojamo energoresursu izmantošana palielina neatkarību no importētiem energoresursiem, samazina siltumnīcefekta gāzu emisijas apjomu, kā arī palielina energijas apgādes drošību. Tomēr energèetiḳi atzīst, ka energosistēmas kḷūst ievainojamākas, jo vēsturiskās, patstāvīgās bāzes jaudas tiek aizvietotas ar ražošanu no atjaunojamiem energoresursiem. Tas saistìts ar subsīdijām, jo investīciju prioritāte ir rentablākie atjaunojamo resursu projekti. Tādējādi ir jāpievēršas risinājuma izstrādei, kā nepastāvīgos un neprognozējamos atjaunojamos energoresursus integrēt Eiropas elektroenerğijas tirgū, vienlaikus nodrošinot drošu un nepārtrauktu elektroapgādi.

\section{Legal Regulation of Renewable Energy}

\section{Abstract}

Use of renewable energy increases independence from imported energy, reduces greenhouse gas emissions, as well as increases security of energy supply. However, energy industry concedes that power becomes more vulnerable because of historical paradigms; independent power base is replaced with production from renewable energy sources. This is due to subsidies in the investment priority being cost-effective renewable resources projects. Thus, it is necessary to develop a solution defining how volatile and unpredictable renewable energy sources integrated into the European electricity market can be, while ensuring safe and uninterrupted power supply.

Keywords: renewable energy, energy markets, power generation. 


\section{Literatūra}

1. Šel̦epova, K. Elektroenerǵijas tirgus liberalizācijas tiesiskais regulējums. Bakalaura darbs. Rīga: RSU, 2013.

2. Energétika Latvijā. Politikas apskats - beta versija. Iegūts no: http://energetika-lv.wikidot.com/aer

3. 2009. gada 23. aprīla Eiropas Parlamenta un Padomes Direktìva 2009/28/EK par atjaunojamo energoresursu izmantošanas veicināšanu un ar ko groza un sekojoši atcel Direktìvas 2001/77/ EK un 2003/30/EK. Iegūts no: http://old.eur-lex.europa.eu/LexUriServ/LexUriServ.do?uri=OJ :L:2009:140:0016:0062:LV:PDF

4. Ministru kabineta 2010. gada 16. marta noteikumi Nr. 262 "Noteikumi par elektroenerǵijas ražošanu, izmantojot atjaunojamos energoresursus, un cenu noteikšanas kārtību”. Iegūts no: http://www.likumi.lv/doc.php?id=207458

5. Elektroenergijas tirgus likums. Latvijas Republikas likums pieṇemts 2005. g. 5. maijā, ar grozījumiem, kas pienemti lïdz 2012. g. 1. janv. Iegūts no: http://www.likumi.lv/doc.php?id=108834

6. 2009. gada 19. augusta Sabiedrisko pakalpojumu regulēšanas komisijas padomes lēmums Nr. 1/2 "Obligātā iepirkuma komponenšu aprēḳināšanas metodika”. Iegūts no: http:// www.likumi.lv/doc.php?id=196347

7. Ministru kabineta 2011. gada 29. novemra noteikumi Nr. 914 "Elektroenerǵijas tirdzniecības un lietošanas noteikumi”. Ar grozījumiem, kas pieņemti līdz 2012. g. 31. aug. Iegūts no: http:// www.likumi.lv/doc.php?id=241279

8. Ministru kabineta 2010. gada 16. marta noteikumi Nr. 262 "Noteikumi par elektroenerǵijas ražošanu, izmantojot atjaunojamos energoresursus, un cenu noteikšanas kārtību”. Ar grozījumiem, kas pieñemti līdz 2012. g. 8. sept. Iegūts no: http://www.likumi.lv/doc.php?id=207458

9. 2013. gada 27. marts. Sabiedrisko pakalpojumu regulēšanas komisija. Informācija plašsaziṇas līdzekḷiem. Iegūts no: http://www.sprk.gov.lv/?id=16487\&sadala=237 